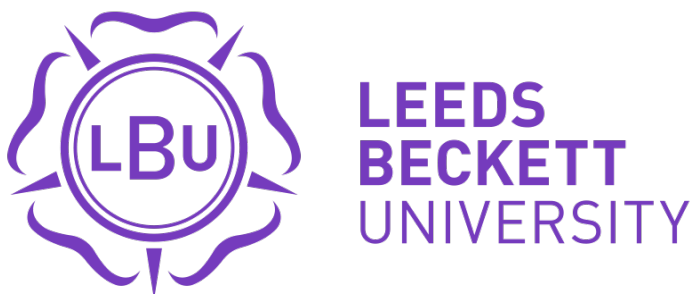

Citation:

Kosmaczewska, J and Thomas, R and Dias, F (2015) Residents' perceptions of tourism and their implications for policy development: evidence from rural Poland. Community Development, 47 (1). 136 - 151. ISSN 1557-5330 DOI: https://doi.org/10.1080/15575330.2015.1110189

Link to Leeds Beckett Repository record:

https://eprints.leedsbeckett.ac.uk/id/eprint/2017/

Document Version:

Article (Accepted Version)

The aim of the Leeds Beckett Repository is to provide open access to our research, as required by funder policies and permitted by publishers and copyright law.

The Leeds Beckett repository holds a wide range of publications, each of which has been checked for copyright and the relevant embargo period has been applied by the Research Services team.

We operate on a standard take-down policy. If you are the author or publisher of an output and you would like it removed from the repository, please contact us and we will investigate on a case-by-case basis.

Each thesis in the repository has been cleared where necessary by the author for third party copyright. If you would like a thesis to be removed from the repository or believe there is an issue with copyright, please contact us on openaccess@leedsbeckett.ac.uk and we will investigate on a case-by-case basis. 


\section{Residents' perceptions of tourism and their implications for policy development: Evidence from rural Poland}

Joanna Kosmaczewska, PhD, University of Economy, Department of Tourism Economy, Garbary 2, 85-229 Bydgoszcz, Poland

Rhodri Thomas, $\mathrm{PhD}$, International Centre for Research in Events, Tourism and Hospitality (ICRETH), Leeds Beckett University, Macaulay Hall, Headingley, Leeds, LS6 5QW

Francisco Dias, PhD, Polytechnic Institute of Leiria, Santuário de Nossa Senhora dos Remédios, 2520-641 Peniche, Portugal

Academics and policy makers have long been interested in understanding the interplay of factors that influence resident perceptions of local tourism development. This article reports the results of a study that is both methodologically and contextually novel. It uses the Chi-square Automatic Interaction Detection (CHAID) method, which is usually associated with other fields, most notably consumer marketing, to examine residents' perceptions of tourism development in rural Poland. It contributes to the literature by revealing the need to segment residents appropriately and highlights which constituencies in rural communities are most likely to be positively (and negatively) disposed toward tourism. This creates opportunities for more nuanced policy interventions.

Keywords: rural; segmentation; CHAID; tourism planning

\section{Introduction}

A recent review of research on residents' perceptions of tourism development revealed how much understanding of this topic has increased over the past twenty years (Sharpley, 2014). Yet, in spite of the prolific output, there remain deficiencies in the literature, which warrant new theoretical, methodological, and empirical contributions. This article responds to Sharpley's (2014) call for additional research by reporting on a case study of residents' attitudes in rural Poland using a novel approach to understanding the phenomenon.

The development of rural areas precipitated by tourism presents a complex set of benefits and costs. These encompass sociocultural considerations (Baum, 2011; Beeton, 2006; Nyaupane, Morais, \& Dowler, 2006) and those relating to local economies (Calado, Rodrigues, Silveira, \& Dentinho, 2011; Manyara \& Jones, 2007; Simpson, 2008) and the 
environment (Dyer, Gursoy, Sharma, \& Carter, 2007). For tourists, rural areas are frequently seen as the embodiment of nature and a set of values and attributes which have all but been lost in urban contexts (Cui \& Ryan, 2011; Dadvar-Khani, 2012; Kastenholz, Carneiro, Eusébio, \& Figueiredo, 2013). Seen this way, members of rural communities represent an important part of the tourist experience, influencing visitor satisfaction and their intention to return (Eusébio, Carneiro, \& Kozak, 2010; Zhang, Inbakaran, \& Jackson, 2006). Equally, there is evidence to suggest that residents' interactions with tourists influences their satisfaction with life in their locality and their intention to support tourism development (Andereck, Valentine, Knopf, \& Vogt, 2005; Sinkovics \& Penz, 2009).

Residents' attitudes toward tourism are explained in the literature in several ways. Advocates of social exchange theory (SET) argue that those who receive direct benefits from the activity - such as employment - tend to have more positive attitudes towards tourism development than those who do not (Andereck et al., 2005; Chuag, 2010; Haley, Snaith, \& Miller, 2005; Nunkoo \& Ramkissoon, 2010). The literature is replete with examples of studies that confirm this proposition (Alhammad, 2012; Chuang, 2010; Deccio \& Baloglu, 2002; Kosmaczewska, 2008; McGehee \& Andereck, 2004; Oviedo-Garcia, Castellanos-Verdugo, \& Martin-Ruiz, 2008; Wang \& Pfister, 2008; Vargas-Sanchez, Plaza-Mejia, \& Porras-Bueno, 2009). Evidence provided by researchers using the tourism area life cycle (TALC), which interprets tourism development as a series of stages through which a destination evolves (exploration, involvement, development, consolidation, and stagnation), suggests that residents' attitudes are positive during the initial stages of tourism development but become negative in the later stages (Allen, Long, Perdue, \& Kieselbach, 1988; Doxey, 1975; Latkova \& Vogt, 2012; Reid, Mair, \& Taylor, 2011). Others have suggested that length of residency negatively influences perceptions of tourism development (Ambroz, 2008). 
Another prominent model used to explain residents' attitudes concerning tourism is the theory of reasoned action (TRA). From this perspective, behavior is influenced by behavioral intent which in turn is influenced by attitudes, and those attitudes are influenced by beliefs. The connections between tourists' attitudes and their behavioral intentions have been identified by several commentators (Dadvar-Khani, 2012; Lepp, 2007; MacKay \& Campbell, 2004; Yu \& Litterell, 2005) and could be seen to apply equally to residents.

In addition to these theoretical perspectives, a systematic review of the literature reveals that several factors appear to influence residents' perception of tourism development (Jackson \& Inbakaran, 2006; Ramseook-Munhurrun \& Naidoo, 2011). The most prominent are: age (young residents are more supportive of tourism development) (Faccioli, 2011); gender (male residents are more supportive) (Dadvar-Khani, 2012; Huh \& Vogt, 2008; Mason \& Cheyne, 2000); and level of education (higher education generates a more supportive attitude) (Korca, 1998). Additionally, knowledge about tourism (the more someone knows about tourism, the more positive attitude towards it they represent) (Andereck et al., 2005; Long, Perdue, \& Allen, 1990); levels of community satisfaction (Diedrich \& Garcia-Buades, 2009); length of residency (Gu \& Ryan, 2008); and level of participation in recreational activities (the more they participate in recreational activities, the more positive tourism impact they perceive) (Gursoy, Jurowski, \& Uysal, 2002). Kosmaczewska (2008) has shown that it is the complex intersection of these factors that shapes residents' attitudes. For a systematic assessment, see Harrill (2004) and Sharpley (2014). Although these studies provide theoretically rich insights, few have adopted novel methods of investigation. One of this article's major contributions is its application of the Chi-square Automatic Interaction Detection (CHAID) method (Kim, Timothy, \& Hwang, 2011) to examine residents' perceptions of tourism. Such an approach enables a more rigorous analysis of key explanatory variables than is often the case when less complex methods are used. 


\section{CHAID in travel and tourism research}

The CHAID algorithm was first introduced in the 1970s by Kass (1980) and has been utilized in other fields, including consumer marketing (Baron \& Phillips, 1994; Riquier, Luxton, \& Sharp, 1997), direct marketing (Elsner, Krafft, \& Huchzermeier, 2003; Schellinck \& Groves, 2002), geography (Casas, 2003), education (Grobler, Bisschoff, \& Moloi, 2002), and gambling (Welte, Grace, Barnes, Wieczorek, \& Tidwell, 2004). CHAID analysis has also appeared in more limited fashion in the tourism literature. It was used, for example, to segment college students taking spring break vacations (Chen, 2003a), understand the process of revisiting and recommending destinations to family and friends (Agapito, Valle, \& Mendes, 2011; Chen, 2003b; Hsu \& Kang, 2007), appreciate the role of destination image in tourist decision-making (Evans, 1993; Vassiliadis, 2008), and examine the importance of information in tourist behavior (Davis, Allen, \& Cosenza, 1988; Byrd \& Gustke, 2011; Joh, Lee, Bin, Arentze, \& Timmermans, 2011). The CHAID method has also been used to segment tourists according to their willingness to pay an accommodation tax (Valle, Pintassilgo, Matias, \& André, 2012) and their shopping preferences (Kim et al., 2011). There are, as far as was determined through this literature review, no instances of CHAID being used to examine residents' perceptions of tourism. This was surprising given its potential explanatory value.

\section{The types of community: conceptual and methodological considerations}

There are numerous definitions of "rural" in economic research (George, Mair, \& Reid, 2009). Currently, the most commonly used in economic research on rural areas in Poland is the one given by The Polish Central Statistical Office (Główny Urząd Statystyczny/GUS, 2011, p.134). It distinguishes between three groups of rural areas as follows: integrated rural areas - these are well developed and are slowly losing their traditional agricultural character 
due to their proximity to big cities; intermediate rural areas - these maintain their agricultural character but also develop their non-agricultural related sources of income, including tourist services; and peripheral rural areas - these are economically marginal but they may have the potential to provide a tourism offer with some niche products (Rakowska \& WojewódzkaWiewiórska, 2010).

This study examines residents' attitudes toward tourism in the context of the contrasting types of community and their demographic features in rural Poland. The research focuses on the attitudes of residents from four different types of communities: "satellite communities" representing integrated rural areas; "star communities" representing intermediate rural areas where tourism already features; "aspiring star communities" which are intermediate rural areas with the potential for tourism development; and "peripheral communities" which are economically marginal but may have the potential to develop a tourism offer via niche products (Rakowska \& Wojewódzka-Wiewiórska, 2010).

Three factors that influence tourism development were also considered in order to present a typology of communities. These were a community's economic and social resources, its resourcefulness, and its level of tourism development (or potential). Each of these factors was expressed by means of an aggregate indicator. In order to assess economic and social resources, a development level indicator was calculated (WPR), as shown in Table 1.

\section{Insert Table 1 about here}

Insert Table 2 about here

Tourism development was represented as WRT (see Table 2). The resourcefulness indicator (WZF) was estimated as follows:

$$
W Z F=\frac{p}{L}-\frac{s+d}{L}
$$

where: 
$p=$ share in taxes allocated to the tourism budget

$s=$ general subsidies

$d=$ budget grants in total

$L=$ number of inhabitants

If the indicators above express positive values, they are deemed to be tourism development stimulants. If their values are negative, they are considered to be the ones that hamper tourism development in a community.

Analysis of the data on the selected communities enabled the identification of four groups as follows. (1) Well-developed communities with a dominant non-tourist function (WZF $>$ WPR $>$ WRT); these are the "satellite communities." (2) Developed communities where a tourist function is significant (WZF $>$ WPR $\geq W R T$ ) are known as the "star communities.” (3) Poorly developed communities that have tourism potential (WZF $<\mathrm{WPR} \leq \mathrm{WRT}$ ) are referred to as the "aspiring star communities." (5) Very poorly developed communities with very limited tourism potential (WZF $<\mathrm{WPR}<\mathrm{WRT}$ ) are noted as the "peripheral communities."

The aim of the study reported here was to establish the extent to which local residents could be segmented, usefully, based on their perceptions of the economic impact of tourism. More specifically, the intention was to address two research questions. Firstly, were there any significant differences between residents' perceptions of tourism development depending on the type of rural community they belong to? Secondly, did residents with positive attitudes concerning tourism's economic impact constitute a homogenous group? The answers to these questions are potentially valuable to local government and other institutions with a role in managing tourism in these rural areas. In addition, the research might also be used as a starting point in developing residents' involvement in decision making on issues such as the 
scope and density of tourism development (Brida, Osti, \& Barquet, 2010). As is argued later, the findings help provide theoretical advances that have potentially significant practical implications.

\section{Research design and methods}

Locations representing the community types discussed above were chosen for the empirical survey of residents using the Ward method (Park \& Yoone, 2009; Vargas-Sanchez, PlazaMejia, \& Porras-Bueno, 2011) and utilizing official sources (Czarnecki \& Frenkel, 2015). The Manhattan city-block distance (Shoval \& Raveh, 2004) was then applied to create clusters and, finally, the k-means method (Mundet \& Coenders, 2010) was used to group the communities into clusters. The communities chosen for the empirical study were the ones closest to the center of the cluster. Additionally, the communities had to show evidence of possessing registered tourist accommodation. By selecting the sample locations on this basis, it is reasonable to treat them as being representative of particular types of communities, enabling generalizations to be made.

From a possible three hundred and forty-eight rural communities in the Lake District, eight were selected for this study. These were seen as being of particular interest in a tourism and development context because of the similarities in their natural resources but differences in their socioeconomic composition. These eight communities are described below.

- Osielsko Commune is located in the kujawsko-pomorskie voivodeship (or administrative area). It is the richest commune in this voivodeship. Its wealth emanates from the high income tax generated from residents. This community is located very close to Bydgoszcz city. 
- Dragacz Commune is located in the kujawsko-pomorskie voivodeship. The community lies entirely within the Vistula Landscape Park. It is comprised of mainly agricultural land and forests.

- Czernikowo Commune is located in the kujawsko-pomorskie voivodeship. The most prominent characteristic of this commune is the preponderance of forests ( 44 percent of the land).

- Chrostkowo Commune is located in the kujawsko-pomorskie voivodeship. The vast majority of land is used for agricultural purposes (81 percent).

- Miasteczko Krajeńskie Commune is located in the wielkopolskie voivodeship. The commune is mainly agricultural land and forests.

- Lipka Commune is located in the wielkopolskie voivodeship and is comprised of land used mainly for agriculture and forest.

- Przechlewo Commune is located in the pomorskie voivodeship. There are three nature reserves within the boundaries of this commune.

- Liniewo Commune is located in the pomorskie voivodeship. There is a nature reserve within the boundaries of this commune.

In order to capture the main attributes that could be used to identify residents' perceptions towards tourism development, 1,000 randomly selected residents were surveyed. A Computer Aided Telephone Interviewing (CATI) system, which generated random telephone numbers, was used for selection purposes. The sample included 234 residents from satellite communities, 336 from star communities, 203 from aspiring star communities, and 227 from peripheral communities (see Table 3). The survey was conducted among residents who were not employed in the tourism sector. All of those surveyed were of an economically productive age. The sample constituted 3.12 percent of those of economically productive age 
(defined officially in Poland as 18 to 59 years old for females and 18 to 64 years old for males). The size of the sample was designed to achieve a confidence interval of 0.95 and a maximum standard deviation of 3.15 percent. The survey was administered via a CATI system and had a response rate of 78.5 percent.

\section{Insert Table 3 about here}

Questionnaire design was informed by the literature review and included questions on perceptions of tourism development, respondents' personal circumstances (including income), and on the labor market. Residents were asked to answer each question using a five-point scale ranging from one (definitely not) to five (definitely) (Bigne, Sanchez, \& Sanz, 2009; Pike \& Ryan, 2004). The sociodemographic profile of respondents was also garnered and is presented in Table 4. As that table shows, women tended to be more positively disposed to tourism's impact on residents' income.

\section{Insert Table 4 about here}

In order to apply the CHAID methodology, the five original response categories were amalgamated into two (yes and no) and used to develop tree diagrams. This technique involves the creation of a figure whereby the root node comprises the complete sample and each subsidiary node represents a segment of the sample. During this procedure, associations between a dependent variable and a set of independent variables are first examined. This criterion-based technique has several advantages over non-criteria based methods such as cluster analysis (Chen, 2003b). An additional validation check using the split-sample validation method with a training sample of 75 percent of cases and a hold-out sample of 25 percent of cases was undertaken and, as suggested by Keppel (1991), a chi-square test with Bonferroni adjustment was also used.

The most positive attitudes towards tourism impact were observed among residents of star communities. Following the procedure used by Valle et al. (2012), the chi-square 
independence test was used to select the categories of the predictor variables that significantly discriminate between residents' perceptions of tourism impact. Table 5 shows the predictor variables considered in the CHAID analysis and the results from the chi-square tests.

\section{Insert Table 5 about here}

As Table 5 reveals, the variable "tourism has a positive impact on the labor market" is the most important to segment residents in relation to the dependent variable "perceptions towards tourism's impact on residents' income," as it presents the largest chi-square value relative to the chi-square critical value. The second most important variable is the financial circumstances of respondents.

The final tree has an estimated risk of 0.236 , with a standard error of 0.018 . This means that the overall percentage of correct classification is 76.4 percent, which is considered to be a good result (Agapito et al., 2011). Following the procedure suggested by Legohérel and Wong (2006), the CHAID analysis was repeated, using the second most significant variable in Table 3, "self-assessment of financial condition," to enter the first stage of the analysis. The same procedure was applied to the third most significant variable "working in the community." This analysis revealed the same significant predictors presented in Figure 1, indicating the stability of the findings.

\section{Residents' perceptions of tourism}

In Figure 1, the root node shows that only 35.5 percent of the residents surveyed observed positive impacts from tourism based on residents' income. The CHAID dendrogram shows that the best predictors of residents' perceptions towards tourism impact was seeing the positive impact of tourism on the labor market (chi-square $=79.679$; adj. $\mathrm{p}<.001)$. This suggests that residents understand how tourism may directly or indirectly influence their income. Specifically, this dependent variable was the most important predictor in the CHAID 
model, splitting respondents into two distinctive segments. One of them includes 46.8 percent of respondents who believe that tourism has a positive impact on residents' income. The second split is attributed to the variable relating to the respondents' own financial situation (chi-square $=53.151$; adj. $\mathrm{p}<.001)$. Those who declared very comfortable circumstances noted that tourism made a positive impact on residents' income (74.4 percent).

Node 4, representing the respondents who had good and more challenging financial conditions, and who did not consider tourism had a particular impact on their incomes, is further divided into two smaller nodes: Node 7 and Node 8, using the variable of "type of rural community" (chi-square $=15.562$; adj. $\mathrm{p}<.001$ ). The results presented show that the type of community constitutes a significant variable when related to perceptions of tourism's economic impact by members of a particular community $($ chi-square $=15.562$; adj. $\mathrm{p}<.001)$. There was little sense that tourism had a positive impact on the inhabitants' income (58.6 percent) among those living in satellite, star, or peripheral communities and especially not among those inhabiting aspiring star communities (where the comparable figure is 84.5 percent). Such a situation may be explained by the fact that the tourist flow is relatively low in these types of communities, and the investments made in tourist infrastructure as well as actions taken in to increase demand for tourist services have not brought the desired effect.

The CHAID analysis also shows that respondents who had less than a high school level of education (chi-square $=7.160$; adj. $p=0.022)$ showed more positive perceptions towards tourism's economic impact (54.4 percent) than residents who had gained high school or university level education (34.8 percent). The findings demonstrate as well that working in the community is a significant explanation of the dependent variable (chi-square $=15.422$; adj. $\mathrm{p}<.001$ ), which led to the tree being divided into two nodes: Node 5 (those who worked in the community) and Node 6 (those who did not work in the community). The results reveal that residents who worked in the community showed more positive perceptions towards 
tourism's impact than residents who worked outside the community. However, taking into account residents' perceptions towards tourism's economic impact on their own financial condition is a more significant variable than working in a community.

\section{Insert Figure 1}

Figure 1 Tree diagram generated by the CHAID procedure

Based on the decision tree (Figure 1), six homogeneous segments of residents can be identified, corresponding to the terminal nodes $3,5,6,7,9$, and 10 . Table 4 presents the gain index for each node. There are two nodes with gains of more than one hundred percent in relation to the category "yes" of the dependent variable. Overall, these nodes represent the segments with above average positive perceptions of tourism's impact on residents' income. These are segment 1 (Node 3) and segment 2 (Node 9). For example, the gain index for segment 1 (Node 3) is 208.5 percent, meaning that the positive perceptions of tourism impact on residents' income of this segment is 2.08 times greater than the average.

\section{Insert Table 6 about here}

Segment 1 (Node 3) represents "strongly positive oriented residents." In this study they are labeled the "enthusiastic group," that is, those who see tourism as a mechanism for local economic development. The sociodemographic characteristics show that this segment of residents include people who feel they are in a secure financial position; most of them are employed (85.1 percent) and have a high school level of education (43 percent). It must be emphasized that the enthusiastic group is represented by a large share of young people (27.3 percent). The enthusiasts included 8.3 percent of the inhabitants of satellite type communities, 28.9 percent of those from star type communities, 22.3 percent from aspiring star type communities, and as many as 40.5 percent from peripheral type communities. 
Segment 2 (Node 9) represents residents who express a moderately positive attitude towards tourism's impact. In this study they are labeled "tourism supporters." All of them had very low levels of education and the majority of them were aged between 50 and 59 (52.9 percent). Taking into consideration the fact that 52.9 percent of them are unemployed, one conclusion that may be drawn is that they perceive tourism as a supplementary activity, which may bring opportunities for additional paid employment.

The chi-square tests show significant statistical differences in categorical variables between the two types of segment. The tests illustrate that the "enthusiastic group" and "tourism supporters" reveal heterogeneity in connection with the following traits: age (chisquare $=21.573 ; \mathrm{p}<.001)$, level of education (chi-square $=86.810 ; \mathrm{p}<.001)$, employment $($ chi-square $=29.071 ; p$-value $<.001)$, working in the community $($ chi-square $=32.221 ; p<$ .001 ), self-assessment of financial condition (chi-square $=189.000 ; \mathrm{p}<.001$ ), and type of rural community $($ chi-square $=19.364 ; \mathrm{p}<.001)$. A comparison of the two segments representing the residents with the most positive attitudes towards tourism is presented in the Table 7.

\section{Insert Table 7 about here}

Kendall Tau coefficients were calculated to determine the strength of association of variables. This was used because it is a unified measure of association across the different types of data gathered. The Kendall Tau rank correlation coefficient enables the variables analyzed to be ranked according to strength of dependence, which resulted in the following: the level of education of the respondents $(\tau=.056, \mathrm{p}<.05)$, self-assessment of financial condition $(\tau=.051, \mathrm{p}<.05)$, age $(\tau=.047, \mathrm{p}<.05)$, type of rural community $(\tau=.041, \mathrm{p}<$ $.05)$, employment $(\tau=.036, \mathrm{p}<.05)$, and working in the community $(\tau=-.016, \mathrm{p}<.05)$. These results indicate, therefore, that a person's level of education is the most important factor influencing residents' positive perceptions of tourism. 


\section{Conclusion}

The research reported in this article suggests that only 35 percent of residents in Polish rural communities perceive a positive influence on their income arising from tourism. This appears to confirm the observation made by others that the benefits of tourism are often distributed unevenly within communities (Fredline \& Faulkner, 2000; Getz, 1994; Han, Fang, \& Huang, 2011; Kuvan \& Akan, 2005; Prentice, 1993). Nevertheless, a high percentage of residents (72.3 percent) claim that tourism has a positive influence on the local labor market indicating that they appreciate that tourism may influence residents' income, both directly and indirectly.

On the basis of this research, it seems that the "community type" is a statistically important variable that differentiates residents' perceptions of tourism's economic impact. Residents of "aspiring star communities" showed less positive attitudes which may be explained by the fact that in these communities, the tourist flow is relatively low, investment in the tourist infrastructure is less noticeable, and actions taken to increase demand for tourist services have not brought the desired effects.

Residents' assessment of their financial position, however, appeared to be a much more significant factor. These results support the thesis that positive perceptions of the economic impact of tourism is significantly influenced by a sense of material wellbeing (Kim, Uysal, \& Sirgy, 2012). The research has also shown that in the rural areas studied, residents with lower levels of educational attainment had more positive perceptions of tourism's economic impact (54.4 percent), a finding that is consistent with those of Latkova and Vogt (2012).

The CHAID procedure allowed for the identification of six segments of residents in light of their perception of tourism's influence on residents' income. Two segments, including residents with the most positive attitudes, were analyzed in detail. This revealed that residents 
were not homogeneous in their attitudes to tourism development. Indeed, two groups were distinguished: the enthusiastic group and the tourism supporter group. On the basis of the chisquare test, it was demonstrated that these two groups showed statistically significant difference concerning such features as: age, education level, type of employment, work in communities, self-assessment of financial condition, and type of community to which they belong. These results partially correspond with the results of research conducted in rural Italy (Brida et al., 2010) and in China (Huang, 2011).

Finally, this study has shown that the profile of resident communities (including the type of rural community) helps explain the variation in perceptions towards tourism's economic impact. This has important implications for policy makers as community perceptions are likely to play a significant enabling or constraining role in tourism planning. This is because support for the development of tourism by residents is necessary to ensure the long-term success of destinations (Aref, Redzuan, \& Gill, 2009). On the basis of the evidence presented in this article, policy makers can now anticipate differential levels of support for tourism depending upon the characteristics of community being considered. This, in turn, implies a need for more (or less) intensive strategies for engaging with communities about the potential role of tourism in community development. Although it is inappropriate to recommend specific interventions that might prove fruitful, as these are likely to emerge from a more nuanced understanding of local conditions, the expectations of support (or disapproval) are broadly predictable and are helpful as a starting point for local policy making.

Inevitably, this study has limitations. Some of these are common concerns for studies of this kind, such as the quality of insight offered to researchers who are not familiar with the locality. Perhaps of greater note, however, is the uncertainty over the extent to which insights from Polish rural communities may be useful for other parts of Europe and beyond, notably 
developing economies. Further, the quantitative approach adopted has yielded valuable insights but additional qualitative inquiry would potentially reveal more of the dynamics at play. We recommend that each of these is addressed in future research.

\section{References}

Agapito, D., Valle, P., \& Mendes, J. (2011). Tourist recommendation through destination image: a CHAID Analysis. Tourism and Management Studies, 7, 33-42.

Alhammad, F. J. (2012). Residents' attitudes towards tourism development in AL-Salt City. Canadian Social Science, 8, 151-162.

Allen, L. R., Long, P. T., Perdue, R. R., \& Kieselbach, S. (1988). The impact of tourism development on residents' perceptions of community life. Journal of Travel Research, $27,16-21$.

Ambroz, M. (2008). Attitudes of local residents towards the development of tourism in Slovenia: The case of the Primorska, Dolenjska, Gorenjska, and Ljubljana regions. Anthropological Notebooks, 14, 63-79.

Andereck, K. L., Valentine, K. M., Knopf, R. C., \& Vogt, C. A. (2005). Residents' perceptions of community tourism impacts. Annals of Tourism Research, 32, 10561076.

Aref, F., Redzuan, M., \& Gill, S. (2009). Community perceptions toward economic and environmental impacts of tourism on local communities. Asian Social Science, 5, 130137.

Baron, S., \& Phillips, D. (1994). Attitude survey data reduction using CHAID: An example in shopping centre market research. Journal of Marketing Management, 10, 75-88.

Baum, S. (2011). The tourist potential of rural areas in Poland. Eastern European Countryside, 17, 107-135. 
Beeton, S. (2006). Community development through tourism. Landlinks Press, Victoria, Australia

Bigne, E., Sanchez, I., \& Sanz S. (2009). The functional-psychological continuum in the cognitive image of destination: A confirmatory analysis. Tourism Management, 30, 19.

Brida, J., Osti, L., \& Barquet, A. (2010). Segmenting residents' perceptions towards tourism a cluster analysis with multinomial logit model of Mountain Community. International Journal of Tourism Research, 12, 591-602.

Byrd, E. T., \& Gustke, L. (2011). Using decision trees to identify tourism stakeholders. Journal of Place Management and Development, 4, 148 - 168.

Calado, L., Rodrigues, A., Silveira, P., \& Dentinho, T. (2011). Rural tourism associated with agriculture as an economic alternative for the farmers. European Journal of Tourism, Hospitality and Recreation, 2, 155-174.

Casas, I. (2003). Evaluating the importance of accessibility to congestion response using a GIS-based Travel Simulator. Journal of Geographical Systems, 5, 109-127.

The Central Statistical Office (2011). Rural areas in Poland, Regional and Environmental Surveys Division. Warsaw, Poland, (1-220). http://stat.gov.pl/cps/rde/xbcr/gus/af_rural_areas_in_poland_2010.pdf

Chen, J. S. (2003a). Developing a travel segmentation methodology: A criterion-based approach. Journal of Hospitality and Tourism Research, 27, 310-327.

Chen, J. S. (2003b). Market segmentation by tourists' sentiments. Annals of Tourism Research, 30(1), 178-193.

Chuang, S. T. (2010). Rural tourism: Perspectives from social exchange theory. Social Behavior and Personality, 38, 1313-1322. 
Cui, X., \& Ryan, C. (2011). Perceptions of place, modernity and the impacts of tourism Differences among rural and urban residents of Ankang, China: A likelihood ratio analysis. Tourism Management, 32, 604-615.

Czarnecki, A., \& Frenkel, I. (2015). Counting the 'invisible': Second homes in Polish statistical data collections. Journal of Policy Research in Tourism, Leisure and Events, $7,15-31$.

Dadvar-Khani, F. (2012). Participation of rural community and tourism development in Iran. Community Development, 43, 259-277.

Davis, D., Allen, J., \& Cosenza, A. (1988). Segmenting local residents by their attitudes, interests, and opinions towards tourism. Journal of Travel Research, 27, 2-8.

Deccio, C., \& Baloglu, S. (2002). Nonhost community resident reactions to the 2002 winter Olympics: the spillover impacts. Journal of Travel Research, 41, 46-56.

Diedrich, A., \& Garcia-Buades, E. (2009). Local perceptions of tourism as indicators of destination decline. Tourism Management, 30, 512-521.

Doxey, G. V. (1975). A causation theory of visitor-resident irritants' methodology and research inferences. Proceedings of the Sixth Annual Conference of the Travel Research Association (pp. 195-198), San Diego CA: Travel and Tourism Research Association.

Dyer, P., Gursoy, D., Sharma, B., \& Carter, J. (2007). Structural modeling of resident perceptions of tourism and associated development on the Sunshine Coast, Australia. Tourism Management, 28, 409-422.

Elsner, R., Krafft, M., \& Huchzermeier, A. (2003). Optimizing Rhenania’s mail-order business through dynamic multilevel modeling (DMLM). Interfaces, 33, 50-66. 
Eusébio, C., Carneiro, M.J., \& Kozak, M. (2010). Determinants of tourist-host interactions: a youth market analysis. Proceedings Book of the 5th World Conference for Graduate Research in Tourism, Hospitality and Leisure. Turkey: Detay Yayincilik, 92-113

Evans, T. R. (1993). Residents’ perceptions of tourism in New Zealand communities. Dunedin, New Zealand: University of Otago.

Faccioli, M. (2011). Youth`s perceptions of tourism impact: policy implications for Folgaria (Italy). International Journal Tourism Policy, 4, 1-35.

Fredline, E., \& Faulkner, B. (2000). Host community reactions: a cluster analysis. Annals of Tourism Research, 27, 763-784.

George, E. W., Mair, H., \& Reid, D. G. (Eds.). (2009). Rural tourism development: Localism and cultural change. Bristol, UK: Channel View Publications.

Getz, D. (1994). Resident attitudes toward tourism: a longitudinal study of the Spey Valley, Scotland. Tourism Management, 15, 247-258.

Gu, H., \& Ryan, C. (2008). Place attachment, identity and community impacts of tourismthe case of Beijing Hutong. Tourism Management, 29, 637-647.

Gursoy, D., Jurowski, C., \& Uysal, M. (2002). Resident attitudes: a structural modeling approach. Annals of Tourism Research, 29, 79-105.

Grobler, B. R., Bisschoff, T. C., \& Moloi, K. C. (2002). The CHAID Technique and the relationship between school effectiveness and various independent variables. International Studies in Educational Administration, 30, 44-56.

Haley, A. J., Snaith, T., \& Miller, G. (2005). The social impacts of tourism - a case study of Bath, UK. Annals of Tourism Research, 32, 647-668.

Han, G., Fang W., \& Huang Y. (2011). Classification and influential factors in the perceived tourism impacts of community residents on nature-based destinations: China's Tiantangzhai scenic area. Procedia Environmental Sciences, 10, 2010-2015. 
Harrill, R. (2004). Residents' attitudes towards tourism development: A literature review with implications for tourism planning. Journal of Planning Literature, 18, 251-266.

Hsu, C., \& Kang, S. (2007). CHAID-based segmentation: International visitors' trip characteristics and perceptions. Journal of Travel Research, 46, 207-216.

Huh, C., \& Vogt, C. A. (2008). Changes in residents' attitudes toward tourism over time: A cohort analytical approach. Journal of Travel Research, 46, 446-455.

Jackson, M., \& Inbakaran, R. (2006). Evaluating residents` attitudes and intentions to act towards tourism development in regional Victoria, Australia. International Journal of Tourism Research, 8, 355-366.

Joh, C. H., Lee, B., Bin, M., Arentze, T., \& Timmermans, H. (2011). Exploring the use of travel information - identifying contextual market segmentation in Seoul. Korea Journal of Transport Geography, 19, 1245-1251.

Kass, G. V. (1980). An exploratory technique for investigating large quantities of categorical data. Applied Statistics, 29, 119-127.

Kastenholz, E., Carneiro, M. J., Eusébio, C., \& Figueiredo, E. (2013). Host-guest relationships in rural tourism: evidence from two Portuguese villages. Anatolia - An International Journal of Tourism and Hospitality Research, 24, 367-380.

Keppel, G. (1991). Design and analysis: A researcher`s handbook (3rd ed.). Englewood Cliffs, NJ: Prentice Hall.

Kim, S., Timothy D., \& Hwang, J. (2011). Understanding Japanese tourists's shopping preferences using the Decision Tree Analysis method. Tourism Management, 32, 544554.

Kim, K., Uysal, M., \& Sirgy, J. (2012). How does tourism in a community impact the quality of life of community residents? Tourism Management, 12, 1-14. 
Korca, P. (1998). Resident perceptions of tourism in a resort town. Leisure Sciences, 20, 193212.

Kosmaczewska, J. (2008). The relationship between development of agrotourism in Poland and the local community potential. Studies in Physical Culture and Tourism, 15, 141148.

Kuvan, Y., \& Akan, P. (2005). Residents' attitudes toward general and forest-related impacts of tourism: the case of Belek, Antalya. Tourism Management, 26, 691-706.

Latkova, P., \& Vogt, C. A. (2012). Residents`attitudes toward existing and future tourism development in rural communities. Journal of Travel Research, 51, 50-67.

Lepp A. (2007). Residents' attitudes towards tourism in Bigodi village, Uganda. Tourism Management, 28, 876-885.

Legohérel, P., \& Wong, K. (2006). Market segmentation in the tourism industry and consumers' spending: what about direct expenditures? Journal of Travel and Tourism Marketing, 20, 15-30.

Long, P. T., Perdue, R., \& Allen, L. (1990). Rural resident perceptions and attitudes by community level of tourism. Journal of Travel Research, 28, 3-9.

Manyara, G., \& Jones, E. (2007). Community-based tourism enterprises development in Kenya: An exploration of their potential as avenues of poverty reduction. Journal of Sustainable Tourism, 15, 628-644.

Mason, P., \& Cheyne, J. (2000). Residents' attitudes to proposed tourism development. Annals of Tourism Research, 27, 391-411.

McGehee, N. G., \& Andereck K. L. (2004). Factors predicting rural residents`support of tourism. Journal of Travel Research, 43, 188-200.

MacKay, K. J., \& Campbell, J. M. (2004). An examination of residents' support for hunting as a tourism product. Tourism Management, 25, 443-452. 
Mundet, L., \& Coenders, G. (2010). Greenways: a sustainable leisure experience concept for both communities and tourists. Journal of Sustainable Tourism, 18, 657-674.

Nunkoo, R., \& Ramkissoon, H. (2010). Community perceptions of tourism in small island states: a conceptual framework. Journal of Policy Research in Tourism, Leisure and Events, 2, 51-65.

Nyaupane, G. P., Morais, D. B., \& Dowler, L. (2006). The role of community involvement and number/type of visitors on tourism impacts: a controlled comparison of Annapurna, Nepal and Northwest Yunnan, China. Tourism Management, 27, 13731385 .

Oviedo-Garcia, M., Castellanos-Verdugo M., \& Martin-Ruiz, D. (2008). Gaining residents support for tourism and planning. International Journal of Tourism Research. 10, 95109.

Park, D., \& Yoon, Y. (2009). Segmentation by motivation in rural tourism: A Korean case study. Tourism Management, 30, 99-108.

Pike, S., \& Ryan, C. (2004). Destination positioning analysis through a comparison of cognitive, affective and conative perceptions. Journal of Travel Research, 42, 333342.

Prentice, R. C. (1993). Community driven tourism planning and residents' preferences. Tourism Management, 14, 218-227.

Ramseook-Munhurrun, P., \& Naidoo, P. (2011). Resident`s attitudes towards perceived tourism benefits. International Journal of Management and Marketing Research, 4, 45-56.

Rakowska, J., \& Wojewódzka-Wiewiórska, A. (2010). Spatial diversity of rural areas in Poland and its condition and development perspectives in the context of functional 
connections, Warsaw, Poland: The Ministry of Regional Development in Poland (in Polish), pp.4

Reid, D. G., Mair, H., \& Taylor, J. (2011). Community participation in rural tourism development. World Leisure Journal, 42, 20-27.

Riquier, C., Luxton, S., \& Sharp, B. (1997). Probabilistic segmentation modelling. Journal of the Market Research Society, 39, 571-88.

Schellinck, T., \& Groves, K. (2002). How low can you go? The value of sparse data in retail databases. Journal of Database Marketing, 9, 143-149.

Sharpley, R. (2014). Host perceptions of tourism: A review of the research. Tourism Management, 42, 37-49.

Shoval, N., \& Raveh, A. (2004). Categorization of tourist attractions and the modelling of tourist cities: based on the co-plot method of multivariate analysis. Tourism Management, 25,741-750.

Simpson, M. C. (2008). Community benefit tourism initiatives: a conceptual oxymoron? Tourism Management, 29, 1-18.

Sinkovics, R. R., \& Penz, E. (2009). Social distance between residents and international tourist implications for international business. International Business Review, 18, 457469.

Wang, Y., \& Pfister, R. E. (2008). Residents' attitudes toward tourism and perceived personal benefits in rural community. Journal of Travel Research, 47, 84-93.

Welte, J. W., Grace, M., Barnes, W., Wieczorek, F., \& Tidwell, M. C. (2004). Gambling participation and pathology in the United States: A sociodemographic analysis using classification trees. Addictive Behaviors, 29, 983-9. 
Valle, P. O., Pintassilgo, P., Matias, A., \& André, F. (2012). Tourist attitudes towards an accommodation tax earmarked for environmental protection: A survey in the Algarve. Tourism Management, 33, 1408-1416.

Vargas-Sanchez, A., Plaza-Mejia, A., \& Porras-Bueno, N. (2009). Understanding residents' attitudes toward the development of industrial tourism in a former mining community. Journal of Travel Research, 47, 373-387.

Vargas-Sanchez, A., Porras-Bueno, N., \& Plaza-Mejia, M. (2011). Explaining residents' attitudes to tourism. Is a universal model possible? Annals of Tourism Research, 38, $460-480$.

Vassiliadis, C. (2008). Destination product characteristics as useful predictors for repeat visiting and recommendation segmentation variables in tourism: A CHAID exhaustive analysis. International Journal of Tourism Research, 10, 439-452.

Yu, H., \& Littrell, M. A. (2005). Tourists' shopping orientations for handcrafts: What are key influences? Journal of Travel and Tourism Marketing, 18, 1-21.

Zhang, F., Inbakaran, R. I., \& Jackson, M. (2006). Understanding community attitudes towards tourism and host-guest interaction in the urban-rural border region. Tourism Geographies, 8, 182-204. 


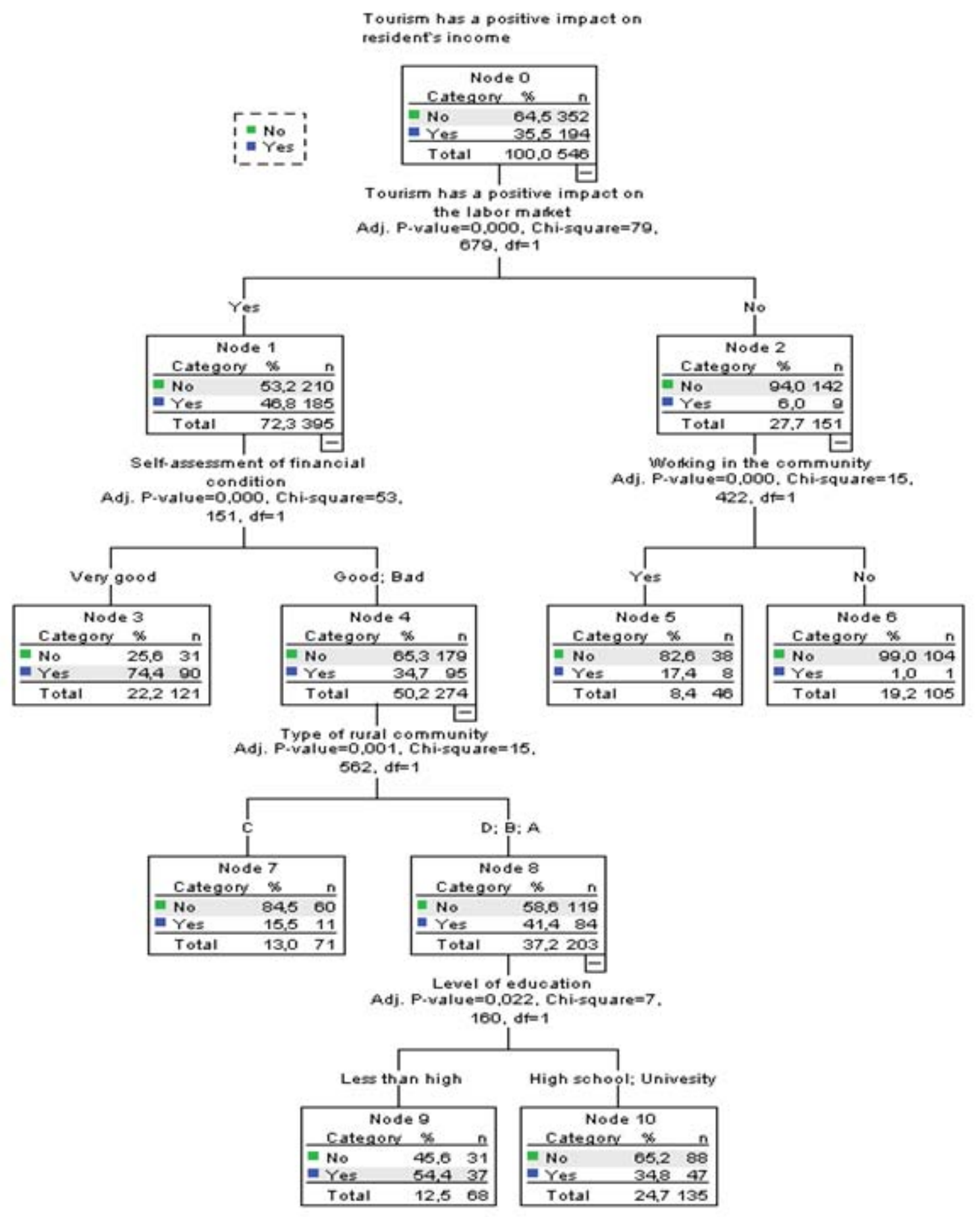

Table 1. The development level indicator structure (WPR). 


\begin{tabular}{ll}
\hline Social component & $\begin{array}{l}\text { Migration attractiveness indicator } \\
\text { \% of the community using water supply and sewerage networks }\end{array}$ \\
\hline Economic component & Commune's budget expenditure per capita \\
& $\begin{array}{l}\text { Commune's own income per capita } \\
\text { Enterprise indicator } \\
\% \text { of the registered unemployed per the total number of inhabitants in } \\
\text { productive age }\end{array}$ \\
\hline
\end{tabular}

Table 2. Tourism development aggregate indicator structure (WRT).

\begin{tabular}{ll}
\hline WRT & Sub-indicators \\
\cline { 2 - 3 } & Intensity of tourist activity indicator (Schneider's) \\
A place's tourist function indicator (Baretje`s and Defert's) \\
Tourist function indicator (Defert's) \\
Accommodation development indicator \\
Accommodation accessibility indicator \\
Forests \\
Parks and greenery \\
Cultural attractiveness indicator \\
Businesses registered in the national economy register REGON in section H per \\
1000 people in productive age \\
Expenditure on culture and national heritage protection per capita
\end{tabular}

Table 3. Composition of the population and sample: residents by community type. 


\begin{tabular}{|c|c|c|c|c|c|c|c|c|}
\hline & \multicolumn{2}{|c|}{$\begin{array}{c}\text { A } \\
\text { Satellite } \\
\text { community }\end{array}$} & \multicolumn{2}{|c|}{$\begin{array}{c}\text { B } \\
\text { Star } \\
\text { community }\end{array}$} & \multicolumn{2}{|c|}{$\begin{array}{c}\mathrm{C} \\
\text { Aspiring star } \\
\text { community }\end{array}$} & \multicolumn{2}{|c|}{$\begin{array}{c}\mathrm{D} \\
\text { Stone } \\
\text { community }\end{array}$} \\
\hline & $\frac{\frac{2}{0}}{\frac{0}{0}}$ & 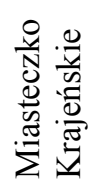 & 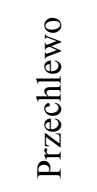 & $\begin{array}{l}\text { Uू. } \\
\text { 品 } \\
\tilde{D}\end{array}$ & $\stackrel{\circ}{\stackrel{0}{g}}$ & $\frac{\pi}{2}$ & 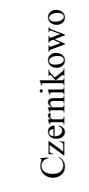 & 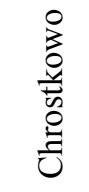 \\
\hline $\begin{array}{l}\text { Number of residents at } \\
\text { economically productive age } \\
\text { (according to GUS) }\end{array}$ & 7486 & 2094 & 4038 & 4662 & 2901 & 3584 & 5431 & 1852 \\
\hline $\begin{array}{l}\% \text { of residents in the } \\
\text { appraisal report }\end{array}$ & 23 & 7 & 13 & 15 & 9 & 11 & 17 & 6 \\
\hline $\begin{array}{l}\text { Minimum size of sample for } \\
\mathrm{n}=1000\end{array}$ & 234 & 65 & 126 & 145 & 91 & 112 & 169 & 58 \\
\hline $\begin{array}{l}\text { Number of subjects taking } \\
\text { part in the research }\end{array}$ & 234 & 65 & 126 & 145 & 91 & 112 & 169 & 58 \\
\hline $\begin{array}{l}\text { Number of subjects taking } \\
\text { part in the research in } \\
\text { different communities }\end{array}$ & \multicolumn{2}{|c|}{234} & \multicolumn{2}{|c|}{336} & \multicolumn{2}{|c|}{203} & \multicolumn{2}{|c|}{227} \\
\hline
\end{tabular}

Table 4. Sociodemographic characteristics of the sample and residents' attitudes towards tourism's impact on their income.

\begin{tabular}{lcc}
\hline Variables & $\begin{array}{c}\text { Distribution of answers } \\
(\%)\end{array}$ & $\begin{array}{c}\text { Tourism has a positive impact on } \\
\text { resident s income (\% answers "yes") }\end{array}$ \\
\hline
\end{tabular}




\begin{tabular}{|c|c|c|}
\hline \multicolumn{3}{|l|}{ Gender } \\
\hline Male & 36.5 & 42.9 \\
\hline Female & 63.5 & 57.1 \\
\hline \multicolumn{3}{|l|}{ Education level } \\
\hline Less than high school & 36.4 & 40.2 \\
\hline High school & 43.2 & 37.5 \\
\hline University & 20.4 & 22.2 \\
\hline \multicolumn{3}{|l|}{ Age } \\
\hline $18-29$ & 13.4 & 17.6 \\
\hline $30-39$ & 18.2 & 18.0 \\
\hline $40-49$ & 22.7 & 23.0 \\
\hline$\geq 50$ & 45.7 & 41.4 \\
\hline \multicolumn{3}{|l|}{ Employment } \\
\hline Yes & 53.4 & 68.6 \\
\hline No & 46.6 & 31.4 \\
\hline \multicolumn{3}{|l|}{ Working in the community } \\
\hline Yes & 36.8 & 60.5 \\
\hline No & 63.2 & 39.5 \\
\hline \multicolumn{3}{|l|}{ Self-assessment of financial condition } \\
\hline \multicolumn{3}{|l|}{ Bad } \\
\hline Good & 8.2 & 5.4 \\
\hline \multirow{2}{*}{ Very good } & 68.9 & 41.3 \\
\hline \multirow{2}{*}{\multicolumn{3}{|c|}{ Share of non-gainful of incomes }} \\
\hline & & \\
\hline $0 \%$ & 47.3 & 49.4 \\
\hline$\leq 20 \%$ & 10.8 & 12.6 \\
\hline$>20-40 \%$ & 9.6 & 13.0 \\
\hline$>40-60 \%$ & 8.9 & 9.2 \\
\hline$>60-80 \%$ & 23.4 & 15.7 \\
\hline \multicolumn{3}{|c|}{ Share of financial liabilities of incomes } \\
\hline $0 \%$ & 52.8 & 56.7 \\
\hline$\leq 20 \%$ & 26.8 & 21.8 \\
\hline$>20-40 \%$ & 12.0 & 8.8 \\
\hline$>40-60 \%$ & 5.3 & 8.0 \\
\hline$>60-80 \%$ & 3.1 & 4.6 \\
\hline \multicolumn{3}{|l|}{ Number of family members } \\
\hline 1 & 14.7 & 15.7 \\
\hline 2 & 25.8 & 25.6 \\
\hline 3 & 19.0 & 21.1 \\
\hline 4 & 22.7 & 21.5 \\
\hline$\geq 5$ & 17.8 & 16.1 \\
\hline \multicolumn{3}{|l|}{ Type of rural community } \\
\hline Satellite community & 23.4 & 14.9 \\
\hline Star community & 33.6 & 44.4 \\
\hline Aspiring star community & 20.3 & 13.0 \\
\hline Stone community & 22.7 & 27.6 \\
\hline
\end{tabular}

Table 5. Chi-square tests between the dependent variable "perceptions towards tourism impact on residents' income" and the predictor variables.

\begin{tabular}{lcc}
\hline Set of predictor variables & Chi-square & $\mathrm{p}$ \\
\hline Tourism has a positive impact on the labor market & 77.904 & .001 \\
\hline
\end{tabular}


Tourism has a positive impact on investments

Self-assessment of financial condition

Working in the community

Type of rural community

Share of non-gainful of incomes

5.938

Share of financial liabilities of incomes

Number of family members

Age

*Non-significant variables (for alpha $=0.01$ )

Table 6. Gains index by node for the target category of the dependent variable (yes).

\begin{tabular}{lcc}
\hline Node & \% of yes & Gain index (\%) \\
\hline 9 & 54.4 & 153.2 \\
10 & 34.8 & 98.0 \\
5 & 17.4 & 49.0 \\
7 & 15.5 & 43.7 \\
6 & 1.0 & 2.8 \\
\hline
\end{tabular}

Table 7. Profile of the segments ( $\%$ of responders). 


\begin{tabular}{|c|c|c|}
\hline & $\begin{array}{l}\text { "enthusiastic } \\
\text { group" }\end{array}$ & $\begin{array}{c}\text { "tourism } \\
\text { supporters" }\end{array}$ \\
\hline \multicolumn{3}{|l|}{ Age $($ chi-square $=21.573 ; \mathrm{p}<.001)$} \\
\hline $18-29$ & 27.3 & 4.4 \\
\hline $30-39$ & 19.0 & 14.7 \\
\hline $40-49$ & 28.1 & 27.9 \\
\hline$>50$ & 25.6 & 52.9 \\
\hline \multicolumn{3}{|c|}{ Level of education (chi-square $=86.810 ; \mathrm{p}<.001)$} \\
\hline High school & 43.0 & 0.0 \\
\hline Less than high school & 29.8 & 100.0 \\
\hline University & 27.3 & 0.0 \\
\hline \multicolumn{3}{|c|}{ Sex $($ chi-square $=6.545 ; \mathrm{p}$-value $=0.999) *$} \\
\hline Female & 56.2 & 57.4 \\
\hline Male & 43.8 & 42.6 \\
\hline \multicolumn{3}{|c|}{ Employment $($ chi-square $=29.071 ; \mathrm{p}<.001)$} \\
\hline No & 14.9 & 52.9 \\
\hline Yes & 85.1 & 47.1 \\
\hline \multicolumn{3}{|c|}{ Working in the community (chi-square $=32.221 ; \mathrm{p}<.001$ ) } \\
\hline No & 23.1 & 66.2 \\
\hline Yes & 76.9 & 33.8 \\
\hline \multicolumn{3}{|c|}{ Self-assessment of financial condition $($ chi-square $=189.000 ; p<.001)$} \\
\hline $\mathrm{Bad}$ & 0.0 & 11.8 \\
\hline Good & 0.0 & 88.2 \\
\hline Very good & 100.0 & 0.0 \\
\hline \multicolumn{3}{|c|}{ Type of rural community (chi-square $=19.364 ; \mathrm{p}<.001$ ) } \\
\hline Satellite community & 8.3 & 8.8 \\
\hline Star community & 28.9 & 47.1 \\
\hline Aspiring star community & 22.3 & 0.0 \\
\hline Stone community & 40.5 & 44.1 \\
\hline
\end{tabular}

*Non-significant variables (for alpha $=0.01$ ) 